\title{
Antimicrobial activity of bacteriocin produced by a local isolate of lactobacillus lactis
}

\author{
Reem Zuhair Shinashal Ena'am Jasim AL.hamdani \\ Department of Biology / College of Girls Education \\ University of Mosul
}

Received
$\mathbf{3 0} / 03 / 2011$

Accepted

05 / 10 / 2011

الخلاصة

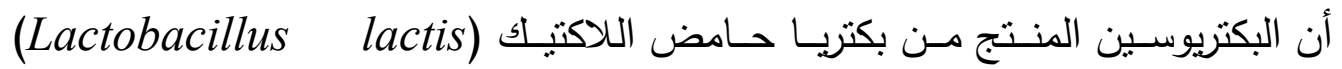

والمعزولة من الحليب البقري الطازج، تَبَيَنَ بأنها ذو تتبـيط واسـع النطاق للجراثيم الموجبة الكرام

Salmonella typhimurium والجـراثيم السالبة لكـرام Staphylococcus aureus و E.coli وتبين أن أعلى إنتاج للبكتريوسين كان في درجة 35؛ وعند أس هيدروجيني 5.5 و 20 ساعة من فترة الحضانة.

\begin{abstract}
Bacteriocin produced by lactic acid bacteria (lactobacillus lactis) isolated from fresh cow milk, showed broad spectrum of antibacterial activity against gram- positive bacteria (Staphylococcus aureus and gramnegative bacteria Escherichia coli, Salmonella typhimurium). Maximum Bacteriocin production was observed at $35^{\circ} \mathrm{c}, \mathrm{pH} 5.5$ and $20 \mathrm{~h}$ of incubation period.
\end{abstract}

\section{Introduction:}

Bacteriocin form lactic acid bacteria are natural antimicrobial peptides. These contain between 30 and 60 residues. They usually have a basic character, and parts of their sequence show amphiphilicity when projected on to a helical wheel. Some bacteriocins undergo posttranslational modification and are called antibiotics $(1,2)$.

Lactic acid bacteria produce a number of antimicrobial substances such as organic acids, ammonia reuterin, diacetyl, hydrogen peroxide. Bacteriocins have the capacity to inhibit the growth of food spoilage and pathogenic organisms $(3,4,5)$. Most of bacteriocins produced by grampositive bacteria are from lactic acid bacteria (6). 
Lactobacillus bacteriocins are found with in each of the four major classes of antimicrobial proteins produced by lactic acid bacteria.

Class I , bacteriocins (antibiotics) were discovered in the lactobacillaceae(7).

These bacteriocins are small membrane - active peptides $(<5 \mathrm{KDg})$ containing an unusual amino acids, kanthionine.

The class II , bacteriocins are small,. heat-stable non lanthionine. containing membrane - active peptides $(<10 \mathrm{KDa})$,

The class III , bacteriocins have been found in lactobacillus, include heat labile proteins of large molecular mass.

The class IV, bacteriocins are a group of complex proteins, associated with other lipid or carbohydrate to be required for activity, they are relatively, hydrophobic and heat stable $(8,9)$.

Bacteriocins have considerable potential for food preservations, as well as for human therapy as potential supplements or replacements for currently used antibiotics $(10,11)$.

In the present work we describe the antibacterial activity of bacteriocin produced by a local isolate of Lactobacillus lactic.

\section{Materials and methods Isolation and culture conditions}

Samples of fresh cow milk were collected for isolation of Lactobacillus lactis, were put in sterile vials, then inoculated on brain heart infusion broth (BHI) and incubated at $37 \mathrm{C}^{\circ}$ for $48 \mathrm{~h}$.anerobically by using candle jar.

Identification of Lactobacillus species was performed according to Bergey's manual of systematic bacteriology

\section{Identification of L. lactis}

The identification of L. lactis was made on the basis of colony morphology and biochemical test, results as Gram positive, rod, Creamy, sticky and smooth round colonies, Uniform, turbidity of Growth in (BHI) Broth, Fermentation positive of Glucose, sucrose, Lactose, mannitol and Positive of $\mathrm{H}_{2} \mathrm{~S}$ production.

\section{Test Bacteria}

Staphylococcus aureus, E.coli, Salmonella typhimurium, were used to demonstrate the antibacterial activity of bacteriocin. These bacteria were obtained from College of Science Department of biology/ university of Mosul .

\section{Assay for antibacterial activity}

The isolated bacterium (L. lactis) was grown in (BHI) broth, $\mathrm{pH}$ 5.5 at $37^{\circ} \mathrm{c}$ for $48 \mathrm{~h}$, incubated anerobically, after that the culture was centrifuged at $10.000 \mathrm{rpm}$ for $15 \mathrm{~min}$, at $4^{\circ} \mathrm{c}$ and then the supernatant was adjusted to $\mathrm{pH} 6.5-7.0$ with $1 \mathrm{~N} \mathrm{NaOH}(11,14)$. The antibacterial activity of the supernatant was determined using the well diffusion method (15). The supernatant from a $48 \mathrm{~h}$ culture of L. lactis was filtered, sterilized by filtration using membrane filter size $(0.45 \mathrm{~mm})$. 
Aliquots $(30 \mu \mathrm{l})$ of the sterile supernatant were placed in 4-mm diameter wells that had been made in nutrient agar plates previously seeded with the test bacteria. S. aureus, E.coli, S. typhimurium. After $24 \mathrm{~h}$ of incubation, the diameters of the zones of growth inhibition surrounding the agar wells, were measured.

\section{Optimization of culture conditions}

The local isolate of L. lactis was subjected to different culture conditions to derive the optimum conditions for bacteriocin production. The growth and bacteriocin production were estimated at various incubation temperature $\left(30,35,40\right.$, and $\left.45^{\circ}\right) \mathrm{pH}(4.5,5.5,6.5$, and 7.5) and incubation period $(5,10,20$ and $40 \mathrm{~h})$, then the antibacterial activity was determined $(16,17)$.

\section{Results and Discussion:}

\section{Antibacterial activity:}

Only (8) isolates of L. lactis were observed to have bacteriocin, effect against (Three) types of bacteria, as shown in the table (1), figure (1).

Table (1): Sensitivity of $S$. aureus, $E$. coli, $S$. typhimurium to bacteriocin produced by $L$. lactis isolate.

\begin{tabular}{|c|c|c|c|c|}
\hline \multirow{4}{*}{$\begin{array}{l}\text { Test Bacteria } \\
\text { S.aureus }\end{array}$} & \multirow{4}{*}{$\begin{array}{c}\text { No. of test Bacteria } \\
3\end{array}$} & \multicolumn{3}{|c|}{ Bacteriocin activity } \\
\hline & & \multirow{2}{*}{\multicolumn{2}{|c|}{$\begin{array}{c}\text { Sensitivity } \\
\text { Zone of inhibition (mm) }\end{array}$}} & \multirow{3}{*}{$\begin{array}{c}\text { - Resistant } \\
1\end{array}$} \\
\hline & & & & \\
\hline & & 2 & $12(\mathrm{~mm})$ & \\
\hline E. coli & 3 & 3 & $18(\mathrm{~mm})$ & 0 \\
\hline S. typhimurium & 3 & 2 & $17(\mathrm{~mm})$ & 1 \\
\hline \multirow{2}{*}{\multicolumn{2}{|c|}{$\begin{array}{l}\text { Total isolates of L. lactis were observed to } \\
\text { have bacteriocin, effect against (Three) } \\
\text { types of bacteria }\end{array}$}} & 6 & & 2 \\
\hline & & \multicolumn{3}{|c|}{8} \\
\hline
\end{tabular}

- No of test Bacteria sensitive to Bacteriocin and Measured by (m.m).

- No of test Bacteria Resistant to Bacteriocin.

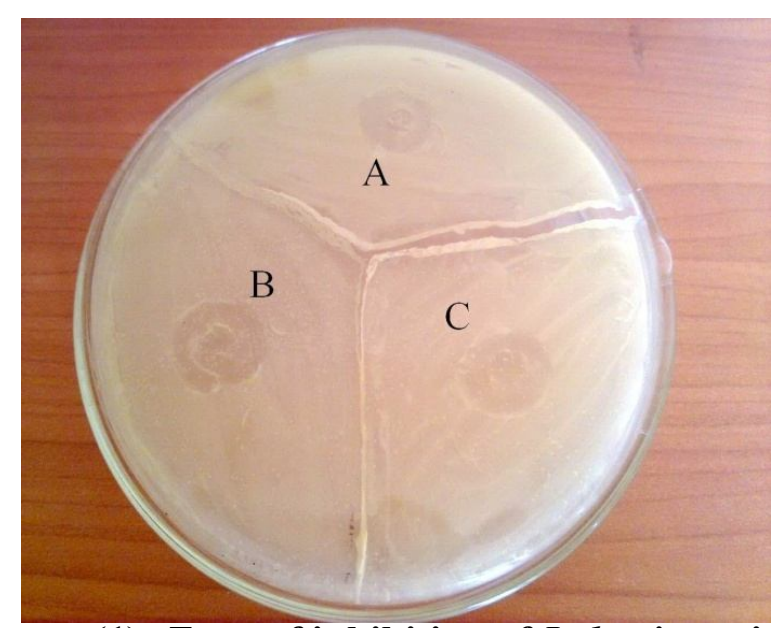

Figure (1): Zone of inhibition of $L$. lactis against:

A: $S$. aureus.

B: $E$. coli .

C: S. typhimurium. 
The present study was primarly aimed for determining cultural conditions for obtaining better and stable, bacteriocin production. L. lactis was able to produce bacteriocin, which had a wide inhibitory spectrum towards pathogenic bacteria. It inhibited all test bacteria S. aureus. E. coli, S. typhimurium, these agree with other published data $(18,19,20)$.

possession of bacteriocin by L. lactis is an indication that this bacteria can be used as probiotic and biopreservative (19).

Incubation temperature, $\mathrm{pH}$ of medium and incubation period. palyed important role in growth as well as bacteriocin production. The bacteriocin activity was tested with different temperature (30, 35, 40 and $45^{\circ} \mathrm{C}$ ). furthermore, the maximum level was obtained at $35^{\circ} \mathrm{C}$, while minimum level was recorded at $30^{\circ} \mathrm{C}$. Regarding $\mathrm{pH}$ the maximum level was obtained at $\mathrm{PH}$ (5.5), and minimum level was at $\mathrm{pH}$ (4.5). Regarding incubation period tested, the high level of baceriocin production was recorded at 20h., while low level was recorded as shown in table (2).

Table (2): Optimization of culture conditions (incubation temperature, $\mathrm{pH}$, and incubation period).

\begin{tabular}{|c|c|c|c|}
\hline $\begin{array}{c}\text { No. of producing isolate of } \\
\text { bacteriocin }\end{array}$ & $\begin{array}{c}\text { Incubation } \\
\text { temperature }\left(\mathrm{C}^{\circ}\right)\end{array}$ & $\mathrm{pH}$ & $\begin{array}{c}\text { Incubation } \\
\text { period (h.) }\end{array}$ \\
\hline $\mathbf{1 , 3 , 5 , 8}$ & $\mathbf{3 5}$ & $\mathbf{5 . 5}$ & $\mathbf{2 0}$ \\
\hline $\mathbf{2 , 6}$ & $\mathbf{3 0}$ & $\mathbf{4 . 5}$ & $\mathbf{5}$ \\
\hline
\end{tabular}

Bacteriocin production was strongly dependent on incubation temperature, $\mathrm{pH}$ and incubation period as claimed by (21). Various physiochemical factor seemed to affect bacteriocin production as well it's activity, similar results were observed $(19,22,23)$.

In conclusion, therefore, the peculiar antimicrobial characteristics of $L$. lactis can positively have impact on their use as starter cultures for traditional fermented foods, with a view to improving the hygiene and safety of the food products.

\section{References}

1) Venema, K. G. venema and T. kok, (1995). Lactococcal bacteriocin: mode of action and immunity. Trends Microbiol., 3: 299- 304.

2) Vingent G. H. Eijlsink, May B. Brurbery, p. Hans Middle Lhoven and Ingolf. F. Nes , (1996) Induction of Bacteriocin production in Lactobacillus Sake by a secreted peptide T. of Bac., Apr., p.22322237.

3) Hol Zapfel, W. H., P. Habere, R. Geisen, J. Bjorkroth and S. Vlrich, (2001) Taxonomy and important features of probiotic micro organisims in food and nutrition. Am. J. clin. Nutr., 73: 365- 373. 
4) Leal- sa'nchez, M.V. Jime' ne z- Daiz, R., Maldonado - Barraga'n, A., Garrido Ferna' dez, A., Ruiz. Barba, J. L. (2002) Optimization of Bacteriocin production by Batch Fermentation of Lactobacillus plantarum, Lpco 10. Appl, And, Envin. Microbiol., 68(9) : 44654474.

5) Hirano, J. T. Yoshida, T. sugiyama, N. Koid, I. Mori and T. Yokochi, (2003) the effect of Lactobcillus rhamnosus on enterohemorrhagic Escherichia Coli infection of human intestinal cells in vitro., Microbiol Immunol., 47: 405- 409.

6) Garneau, S., N. I. Martin and J. c. Vederas, (2002) Tow-peptide bacteriocin produce by lactic acid bacteria, J. Biochem., 84: 577592.

7) Sengul Alpay Karaoglu, Faruk Aydin, S. Sirri Kilic, Ali O. kilic, (2003). Antimcrobial activity and characteristic of bacteriocin produced by vaginal Lactobacilli, Turk J. Med. Sci., 33: 7-13.

8) Twomey D., Ross R. p, Ryan M., Meaney B, Hill c., Lantibiotics produced by Lactic acid bacteria structure, function and applications, Antonie van Leeuwenhook (2002), 82: 165: 185.

9) Eunahar, S. ,T. Sashihara K. Sonomoto and A. Ishizaki, (2000) class IIa bacteriocin biosynthesis, structure and activity, FEMS microbiol. Rew., 24: 85- 106.

10) Fricourt Bv, Barefoot, S. F. Testin RF. Hayaka SS (1994). Detection and activity of plantaricin F. an antibacteria, substance from Lactobacillus palntarum $\mathrm{Bf}$ 001, isolated from processed channel catifich. J. food, prot. 37 (8): 698- 708.

11) Ogunbanwo S. T., Sanni, A. 1. and Onilude A.A. (2003) Influence of cultural conditions on the production of bacteriocin by Lactobacillus brevis OG1, African J. of biotech, vol. 2. (7), pp. 179184 . july.

12) Klander O. and Regular W. N. (1986) Nonsporing gram-positive rods. In: Bergey's manual of systematic bacteriology (Edited by sneath, PHA, Mair NS, Sharpe ME, Holt. JG, pp. 1208-1298, 34 Williams and wilkins Baltimore.

13) Holt, J. G, N. R. , Kriy, J.T. Staley and S.T. Williams, (1994) Gram positive cocci. Bergey's, manual of determinative Bacteriology, $9^{\text {th }}$ Edu., prestons street, Baltimore, Maryland, 21202 USA., pp: 528540.

14) Ammar, S., G.Tauveron, E. Dufour, and I. chevallier (2006) Antibacterial activity of Lactic acid bacteria against spolage and pathogenic bacteria isolated from the same meat small scale facility: 1 screening and characterization of the antibacterial compounds Food control : 17: 454- 461. 
15) Kilic, Ao. Pavlova sl. Ma W. Tao L. (1996) Analysis of Lactobacillus phages and bacteriocin in American dairy products and characterization of a phages isolated from Yogurt. Appl. Environ Microbiol 62: 2111- 2116.

16) Olivera, F.C., G.R, caron, and A. Brandelli: (2004) Bacteriocin production by Bacillus licheniformis strain p40 in cheese whey using response surface methodology. Biochem. Engineer. J: 21: 5358.

17) Jannarsyah, T. (2007) Kajian aktivitas hambat bacteriocin dari bakteri asam laktat galur SCG 1223. Skripsi. Faculty, of agriculture Technology, Bogar Agricultural university, Bogor.

18) Kaoutar, Yaakoubi, Noreddine berkerroum, Florent wiorowski, Francoise sanson, Julien haydersah and isabelle chevallier, (2009), Development of a multiwell antagonistic activity assay for the detection of bactoriocin production by Lactic acid bacteria, J. of rapid methods \& automation in microbiology (17) 32- 45.

19) Rajaram G., Manivasagan p. Thilagavathi, B., Saravanakumar, (2010) purification and a characterization of a bacteriocin produced by Lactobacillus Lactic, isolated from marine environment, Advance J. of food science and Technology 2 (2), 138- 144.

20) Moghaddam, M.Z., M. Sattari, A.M. Mobarez and F. Doctorzadeh, (2006), Inhibitory effect of yogurt Lactobacilli bacteriocins on growth and verotoxins production of enterohemorrhgic Escherichia coil, 0157 : H7. pak. J. Biol. Sci, 9(11): 2112 - 2116

21) Cheigh, C.I., Choi, H. J. park, H. kim, S.B. kook, M.C., Kim, T.S., Hwang, J. k. and pyun, Y. R. (2002) influences of growth conditions on the production of a nisin-like bacteriocin by Lactobacillus lactis subsp. Lactis A 164, isolated from kimchi. J. Biotech, 95: 225- 235.

22) Luc De vuyst Frederic Leroy, (2007). Bacteriocins from Lactic acid bacteria production, purification, and food applications, J. Mol. Microbiol, 13: 194- 199.

23) Karthikeyan, V. and Santosh, S.W. (2009) Isolation and partial characterization of Bacteriocin produced from Lactobacillus plantarum. African, J. of Micro Res. Vol. 3 (5) pp. 233- 239 May. 